\title{
Impact of an invader: epizootic American slipper limpet Crepidula fornicata reduces survival and growth in European mussels
}

\author{
David W. Thieltges* \\ Alfred Wegener Institute for Polar and Marine Research, Wadden Sea Station Sylt, Hafenstrasse 43, 25992 List, Germany
}

\begin{abstract}
Worldwide introductions of species have raised concern about ecological and economic impacts. However, research on actual impacts of introduced species on native biota is rare. The American slipper limpet Crepidula fornicata (L.) was unintentionally introduced to Europe in the 1870s with oysters imported for farming purposes. Since C. fornicata is a filter-feeder, trophic competition and associated negative effects when epizootic on bivalves have been assumed. This study is the first to experimentally test in the field effects of the epizootic $C$. fornicata on survival and growth of its major basibiont in northern Europe, the blue mussel Mytilus edulis L. In 2 field experiments of 12 wk each, epigrowth by $C$. fornicata resulted in a 4 - to 8-fold reduction in survival of mussels, equivalent to a mortality of 28 and $30 \%$, respectively. Shell growth in surviving mussels with attached $C$. fornicata was 3 to 5 times lower compared to unfouled mussels, but similar to that with artificial limpets. As a causative agent, interference competition in the form of changes in small-scale hydrodynamics due to $C$. fornicata stacks is suggested. This may result in a high energy expenditure for byssus production of mussels. Trophic exploitation competition does not seem to be relevant. In general, interference and not exploitation competition is suggested to be the major impact of epizootic C. fornicata on its basibionts in Europe. However, the generality of this assumption has to be verified by investigating different $C$. fornicata-basibiont associations. This stresses the need for a species-by-species approach under diverse environmental settings in assessing impacts of introduced species. In the case of $M$. edulis, this study shows that $C$. fornicata has the potential to act as an important mortality factor.
\end{abstract}

KEY WORDS: Crepidula fornicata - Mytilus edulis · Impact · Introduced species · Epibiosis · Interference competition · Mortality $\cdot$ Growth -Resale or republication not permitted without written consent of the publisher

\section{INTRODUCTION}

The global exchange of species has increased with accelerating speed due to human-mediated transport, and is now considered to be one of the main threats to terrestrial and aquatic ecosystem function and biodiversity (Lodge 1993, Cohen \& Carlton 1998, Grosholz 2002, Pimentel 2002, Olden et al. 2004). However, knowledge on the actual impacts of a specific introduced species on native biota is often anecdotal and detailed evidence is rare (Lodge et al. 1998, Parker et al. 1999, Ruiz et al. 1999, Grosholz et al. 2000).
This also applies to the American slipper limpet Crepidula fornicata (L.), which was unintentionally introduced to Europe in the $1870 \mathrm{~s}$ with oysters imported for farming purposes from the Atlantic coast of North America (Blanchard 1997). Today, its European distribution ranges from southern Norway to Spain, with recent records also from the Mediterranean (Blanchard 1997). The slipper limpet can form dense carpets with up to several thousand individuals $\mathrm{m}^{-2}$. Individuals attach to each other, forming stacks of up to 14 individuals, with the bottommost individual attached to other molluscs like oysters or the blue 
mussel Mytilus edulis (Fig. 1). Since C. fornicata is a filterfeeder, trophic competition has been assumed to be the major impact on native bivalves, with many authors regarding the species as an 'oyster pest' (e.g. Orton 1927, Ankel 1935, Werner 1948, Korringa 1951, Blanchard 1997). Hence, the slipper limpet is mentioned as a potentially serious pest in many introduced species compendia and management guidelines (e.g. Jansson 1994, Eno et al. 1997, Nehring \& Leuchs 1999, Hayes et al. 2002).

However, empirical evidence for trophic competition with other filterfeeding molluscs and concomitant negative effects of Crepidula fornicata on its basibiont is absent. A critical evaluation of the actual impact of this introduced species is still not possible. In addition,

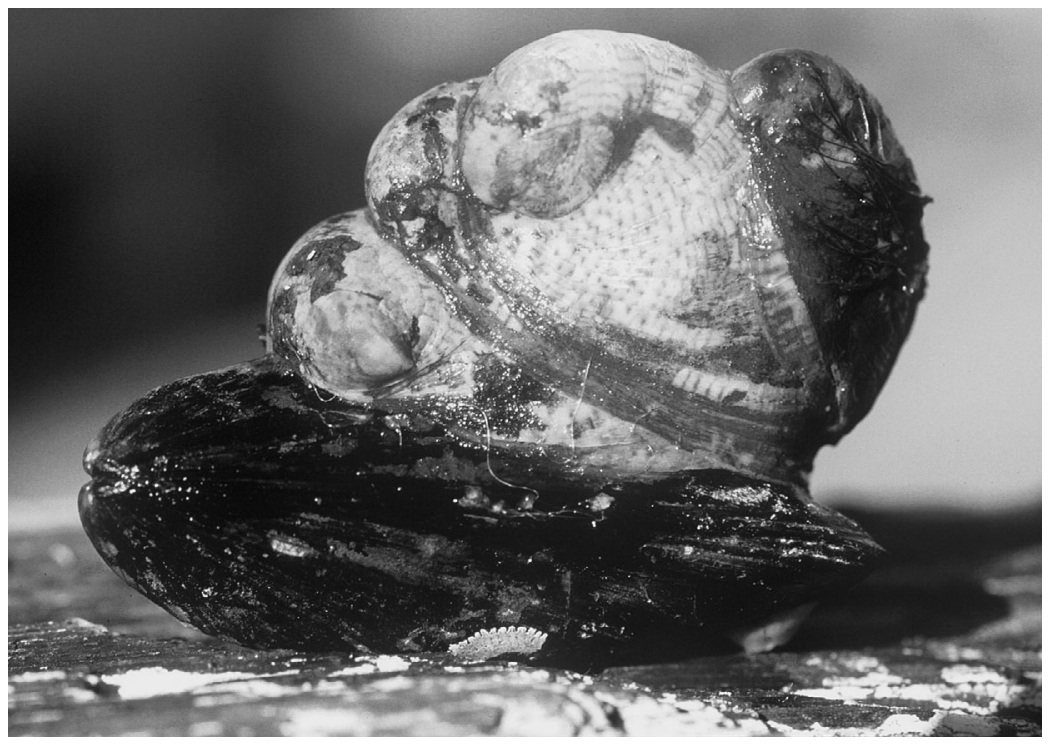

Fig. 1. Stack of 4 American slipper limpets Crepidula fornicata attached to blue mussel Mytilus edulis used in experiments

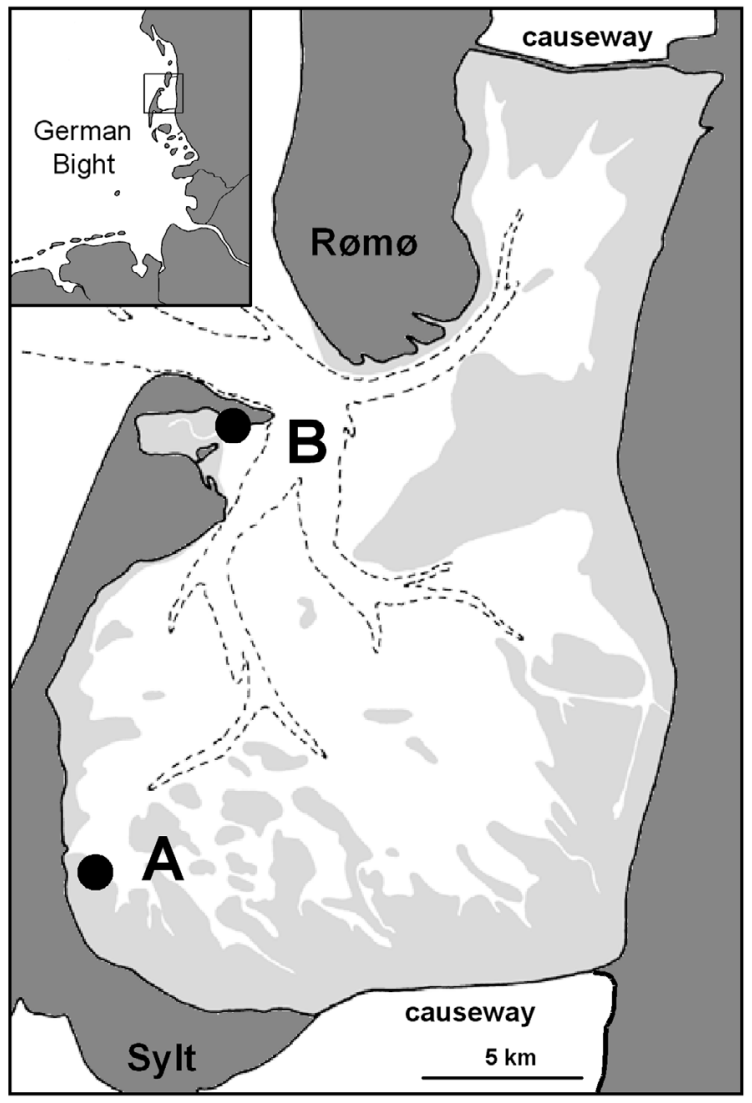

Fig. 2. Study area showing site of collection of Mytilus edulis specimens used in experiments (A) and sites where the field experiments were conducted $(\mathrm{A}$ and $\mathrm{B} ; \boldsymbol{\bullet})$. Light grey shaded areas: intertidal; dashed lines: $10 \mathrm{~m}$ depth contour along channels the few published data on the effects of epizootic Crepidula spp. on their basibionts are contradictory (Peterson 1983, Montaudouin et al. 1999). For the main basibiont of C. fornicata in the northern part of its European range, the blue mussel Mytilus edulis (Thieltges et al. 2003), no data exist at all. Hence, this study was designed to experimentally test the effects of epizootic $C$. fornicata on survival and growth on blue mussels in the field.

\section{MATERIALS AND METHODS}

Study area. Experiments were conducted on 2 mussel (Mytilus edulis) beds in the List tidal basin in the northern Wadden Sea (North Sea, Germany) (Fig. 2). The basin of $407 \mathrm{~km}^{2}$ is barred from the open sea by the islands of Sylt and Rømø. Causeways connect the islands with the mainland. Tides enter the basin via a $2.8 \mathrm{~km}$ wide tidal inlet and are semidiurnal with a mean range of $2 \mathrm{~m}$. Salinity remains close to $30 \%$. Mean water temperature is $15^{\circ} \mathrm{C}$ in summer and $4{ }^{\circ} \mathrm{C}$ in winter. Mussel beds cover approximately $2.7 \%$ of the intertidal (Nehls 2000), while subtidal mussel beds occur mainly as culture plots from the commercial mussel fishery of unreported area. Besides Crepidula fornicata, the epifauna of mussels consist mainly of barnacles. For further information on the area see Gätje \& Reise (1998).

Mussel mortality and growth. Mussels Mytilus edulis with and without epizootic Crepidula fornicata were collected in the shallow subtidal from mean low water (MLW) to $0.5 \mathrm{~m}$ below MLW on a mussel bed in 
the south of the basin (Fig. 2, Site A). Small mussels of 35 to $40 \mathrm{~mm}$ length were used, since their shell growth rates were expected to be higher than those of larger mussels. The size of individual $C$. fornicata ranged from 10 to $30 \mathrm{~mm}$. Two experiments were conducted in different years on different mussel beds.

Expt 1: The first experiment at Site A (Fig. 2) in 2000 consisted of 3 different treatments: (1) unfouled: naturally unfouled mussels (bearing neither Crepidula fornicata nor other epifauna); (2) with C. fornicata: mussels with naturally attached stacks of 3 to 5 C. fornicata (Fig. 1); (3) fake: naturally unfouled mussels with 3 to 5 empty C. fornicata shells glued to their shells with cement (in preliminary experiments the cement had been shown not to affect growth and survival). This experimental set-up was designed to test for effects of C. fornicata as a physical structure (Treatment 1 versus Treatments 2 and 3), as well as for trophic competition (2 versus 3 ) on mussel survival and growth. For each treatment, 30 replicates were used. Since some fakes fell off during the experiment, the number of replicates was reduced to 22 in this treatment. Each mussel was placed in a small cage $10 \mathrm{~cm}$ in diameter and $10 \mathrm{~cm}$ in height, made of polypropylene with a mesh size of $5 \mathrm{~mm}$ and mounted on a wooden board. The cages were fixed with rods in the shallow subtidal $(-0.5 \mathrm{~m}$ MLW) on the mussel bed on the top layer of mussels in a completely randomised design. The experiment started in July and was terminated 12 wk later in October. At the end of the experiment, survival of mussels was determined. The length of each mussel (maximum anterior-posterior axis) was measured with a calliper to the nearest $0.1 \mathrm{~mm}$ at the beginning and end of the experiment. Only mussels that were still alive at the termination of the experiment were used to calculate mean growth increments.

Expt 2: The second experiment was conducted at Site B (Fig. 2) in 2002 with the same treatments as above (1 to 3), but with the addition of a fourth treatment ('cleaned'), comprising mussels whose naturally attached stacks of Crepidula fornicata had been carefully removed with a knife. This experimental set-up allowed testing Treatment 1 versus Treatment 4 to determine if any potential effect of Treatment 2 was due to epizootic $C$. fornicata and not to another correlating factor. For each treatment, 29 replicates were used. Since some fakes fell off during the experiment, the number of replicates was only 25 in this treatment. Each mussel was placed in a bag of polypropylenenetting $(20 \times 20 \mathrm{~cm})$ with a mesh size of $10 \mathrm{~mm}$. The bags were very spacious to prevent any constraints to the experimental units. Installation on the mussel bed and measuring procedures were as for Expt 1. The experiment was started in July and was terminated after 12 wk in October.
Statistical analysis. The graphs and results show arithmetic means and standard errors. Mortality rates were compared with multiple chi-square tests $(2 \times 2$ frequency tables), and Bonferroni corrections were applied (Rice 1999). Growth increments were compared with analysis of variance (1-way ANOVA). Posthoc calculations were done with Tukey's HSD test for unbalanced data sets (Spjotvoll/Stoline) (Day \& Quinn 1989). Data were tested for homogeneity of variance with Cochran's $C$-test and log-transformed in the first experiment to result in homogenous data sets with normal distributions. Since the mussels used were within the same size range with no significant difference in size at the beginning of the experiment, growth rates were not corrected for initial size differences (Kaufmann 1981).

\section{RESULTS}

In both experiments, mortality of mussels with epizootic Crepidula fornicata was 4 to 8 times higher than in unfouled mussels (Fig. 3). At Site A, mortality in mussels with natural $C$. fornicata epigrowth was 4 times higher than in unfouled mussels and similar to that of mussels with fakes. However, the difference between mortality in unfouled mussels and the other 2 treatments was only significant before but not after applying Bonferroni corrections (chi-square, $\alpha$ after Bonferroni correction $=0.017$ ). In the second experiment at Site B, mortality in mussels with natural C. fornicata epigrowth was 3 to 8 times higher than in all other treatments. However, a statistical significance was only detected between naturally unfouled mussels and mussels with $C$. fornicata epigrowth before but not after applying Bonferroni corrections (chi-square, $\alpha$ after Bonferroni correction $=0.0083$ ) .

Growth of mussels was reduced 3- to 5-fold by Crepidula fornicata epigrowth in both experiments (Fig. 3). At Site A, growth was significantly different between the 3 treatments (1-way ANOVA; $F=3.62$; $\left.\mathrm{df}=2 ; \mathrm{df}_{\text {residual }}=62 ; \mathrm{p}<0.05\right)($ Table 1$)$. This was due to an almost 3 times higher growth of unfouled mussels $(0.39 \pm 0.08 \mathrm{~mm})$ compared to mussels with $C$. fornicata epigrowth $(0.15 \pm 0.06 \mathrm{~mm})$ (Tukey's HSD test; $\mathrm{p}<$ $0.05)$. Unfouled mussels grew more than twice as much as mussels with fakes $(0.19 \pm 0.05 \mathrm{~mm})$ but with no statistical significance. In the second experiment at Site $B$, growth was again significantly different between the 4 treatments (1-way ANOVA; $F=5.94$; $\left.\mathrm{df}=3 ; \mathrm{df}_{\text {residual }}=94 ; \mathrm{p}<0.001\right)($ Table 1$)$. This was due to a 3 - to 5 -fold reduction in growth of fouled (natural C. fornicata epigrowth $0.26 \pm 0.15 \mathrm{~mm}$; fake $0.55 \pm$ $0.14 \mathrm{~mm})$ compared to naturally unfouled $(1.34 \pm$ $0.22 \mathrm{~mm}$ ) mussels (Tukey's HSD test; $\mathrm{p}<0.01$ and 

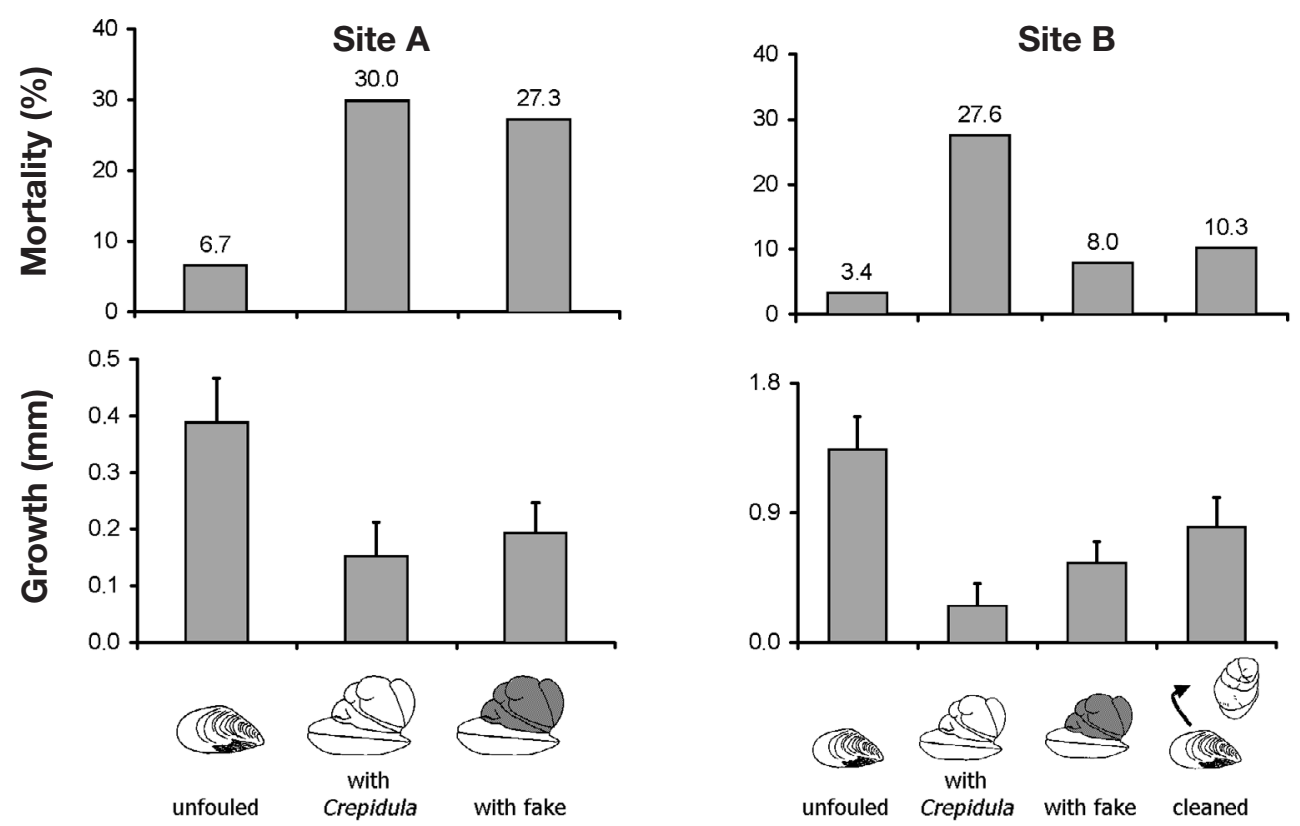

Fig. 3. Mytilus edulis. Mortality and mean (+SE) growth increment in field experiments on effects of Crepidula fornicata epigrowth at Site A in 2000 and Site B in 2002. 'unfouled': naturally unfouled mussels; 'with Crepidula': mussels with natural C. fornicata epigrowth; 'with fake': mussels with empty $C$. fornicata shells glued to their shells; 'cleaned': mussels with natural $C$. fornicata epigrowth removed. Site A: for mortality, $\mathrm{n}=22$ for 'fake' and $\mathrm{n}=30$ for all other treatments; for growth, $\mathrm{n}=28$ for 'unfouled', $\mathrm{n}=21$ for 'with Crepidula' and $\mathrm{n}=16$ for 'with fake' treatments. Site B: for mortality, $\mathrm{n}=23$ for 'fake' and $\mathrm{n}=29$ for all other treatments; for growth, $\mathrm{n}=28$ for 'unfouled', $\mathrm{n}=21$ for 'with Crepidula', $\mathrm{n}=23$ for 'with fake' and $\mathrm{n}=26$ for 'cleaned' treatments

$\mathrm{p}<0.05$, respectively). There was no statistical difference between naturally unfouled mussels and mussels from which $C$. fornicata stacks had been removed $(0.80 \pm 0.2 \mathrm{~mm})$.

\section{DISCUSSION}

Mortality of mussels with natural Crepidula fornicata epigrowth was 4 to 8 times higher than in unfouled mussels. Since there was no statistical difference between mortalities in mussels with $C$. fornicata removed and naturally unfouled mussels in the second experiment at Site B, C. fornicata can be considered to be responsible for the increased mortality. There could be 2 factors responsible for the high mortality observed: (1) C. fornicata stacks reaching into the water column possibly result in enhanced drag forces; this in turn causes the investment of considerably more energy into byssus thread production by mussels to prevent dislodgment (Price 1983, Witman \& Suchanek 1984, Okamura 1986); this extra investment may have resulted in a lethal burden. (2) Alternatively, trophic competition between $C$. fornicata and Mytilus edulis may have resulted in increased mortality; however, since there was no statistical difference in mortality between mussels with $C$. fornicata epigrowth and mussels with fakes, competition for food does not seem to be important. Nevertheless, in the experiment at Site B, mussels with fakes showed a non-significant but apparent lower mortality than mussels with living C. fornicata epigrowth, suggesting that trophic competition might be an additional factor. C. fornicata is preferentially attached to mussel shells with its feedingopening close to the mussel siphon (D. W. Thieltges unpubl. data), thus potentially enabling the snail to participate in the feeding current generated by the

Table 1. Mytilus edulis. Results of post-hoc tests (Spjotvoll/ Stoline-test for unbalanced data sets) of 1-way ANOVAs on growth of mussels in 2 experiments with 3 (Site A) or 4 (Site B) different treatments (see 'Materials and methods'). Significant results are in bold. Site A: 1-way ANOVA; $F=$ 3,$62 ; \mathrm{df}=2 ; \mathrm{df}_{\text {residual }}=62 ; \mathrm{p}<0.05 . \mathrm{n}$ unfouled $=28 ; \mathrm{n}$ with Crepidula fornicata $=21 ; \mathrm{n}$ with fake $=16$. Site B: 1 -way ANOVA $_{i} F=5.94 ; \mathrm{df}=3 ; \mathrm{df}_{\text {residual }}=94 ; \mathrm{p}<0.001$. $\mathrm{n}$ unfouled $=28$; n with $C$. fornicata $=21 ; \mathrm{n}$ with fake $=23$; $\mathrm{n}$ cleaned $=26$

\begin{tabular}{|lccc|}
\hline Treatment & With C. fornicata & With fake & Cleaned \\
\hline Site A & & & \\
Unfouled & $\mathbf{0 . 0 4 9}$ & 0.276 & \\
With C. fornicata & & 0.847 & \\
Site B & & & \\
Unfouled & $\mathbf{0 . 0 0 2}$ & $\mathbf{0 . 0 2 9}$ & 0.178 \\
With C. fornicata & & 0.744 & 0.253 \\
With fake & & & 0.811 \\
\hline
\end{tabular}


mussel. The spectra of food particles filtered by the 2 species overlap (Møhlenberg \& Riisgård 1978, Jørgensen et al. 1984), and the clearance rate of 4 C. fornicata (a common size of a stack) is roughly equivalent to that of a single mussel (Lesser et al. 1992). In addition, recent comparisons of $\delta^{13} \mathrm{C}$ and $\delta^{15} \mathrm{~N}$ values in molluscs suggest similar food sources for $C$. fornicata and M. edulis (Riera et al. 2002). Hence, trophic competition cannot be excluded, but seems to be of minor importance compared to hydrodynamic effects at the sites and time of investigation.

The observed 3- to 5-fold reduction in growth in mussels with Crepidula fornicata epigrowth compared to unfouled mussels corresponds with the result for mortality. There was no statistical difference in growth between naturally unfouled mussels and mussels with C. fornicata removed prior to the experiment. This further confirms that slipper limpets are the cause of the observed reduction in growth. With no statistical difference in growth between mussels with fakes and mussels with living $C$. fornicata epigrowth, trophic competition does not seem to play a crucial role. However, growth of mussels with fakes was up to 2 times higher than in mussels with living $C$. fornicata epigrowth, but still up to 2.5 times lower than in unfouled mussels. This suggests that trophic competition might intermittently occur, although changes in hydrodynamic conditions are definitely a stronger factor, resulting in the observed reduced growth of fouled mussels. That the impact of this factor is a severe and lasting one is indicated by the lower survival and growth of cleaned compared to unfouled mussels, showing that the past presence of $C$. fornicata seems to extract a toll in survival and growth. However, this could also be an effect of the cleaning process prior to the experiment since potential effects of this procedure were not controlled for in the experiment.

Compared to epigrowth with native barnacles - the dominant epizootic of local mussel beds-Crepidula fornicata seems to have a stronger effect on mussels. In field experiments with mussels of similar length, barnacle epigrowth did not affect survival of mussels, and growth of fouled mussels was only reduced to half compared with that of unfouled mussels (Buschbaum \& Saier 2001). Also in that case, hydrodynamic effects and not trophic competition were suggested to be the underlying cause (Buschbaum \& Saier 2001). The larger size of $C$. fornicata stacks in relation to its host might be responsible for a stronger effect compared to barnacles. In addition to survival and growth, epigrowth might also negatively affect reproduction, as reported for other epifauna-basibiont associations (Dittmann \& Robles 1991, Buschbaum \& Reise 1999). For the C. fornicata-mussel association this remains to be investigated. Besides changes in hydrodynamics and competition for food, another factor not tested in the experiments may cause negative effects on basibionts. Epizootic species are likely to hamper the mobility of mussels within the mussel bed when attempting to move in optimal positions to gain the best food. Hence, overgrown mussels might have a disadvantage in intraspecific competition, resulting in lower growth and survival. Reduced mobility might also enhance the risk of getting buried, especially on mussel beds on muddy sediments. However, to my knowledge no experimental studies on such effects of epigrowth on basibionts exist.

The results of this study differ from those of 2 previous experimental investigations on Crepidula-mollusc associations. According to Montaudouin et al. (1999), $C$. fornicata had no effect on survival or growth of the oyster Crassostrea gigas, indicating that no competition exists. On the other hand, Peterson (1983) found that the related epizootic Crepidula onyx reduced growth in the infaunal clam Chione undatella, but did not find effects on mussel survival and suggested trophic competition to be responsible. These differences in the effects of Crepidula spp. on different mollusc species demonstrate that the per se assumption of trophic competition ('oyster pest') and a negative impact of this introduced species is not valid. When evaluting the actual impact of the epizootic $C$. fornicata on its mollusc basibionts, 2 different types of competition (Branch 1984) must be distinguished: (1) Interference competition, whereby $C$. fornicata causes additional drag forces, prompting the basibiont to invest more energy in attachment to its substrate, which may reduce its overall fitness. This mechanism may operate when $C$. fornicata is attached to species that have to expend energy on attachment, such as byssus-producing bivalves. In mussels, C. fornicata results in a twice higher number of byssus threads produced in fouled compared to unfouled mussels (D. W. Thieltges \& C. Buschbaum unpubl. data). However, on other species such as oysters that cement themselves to their substrate, this type of competition should be negligible, as indicated by the experiment of Montaudouin et al. (1999). (2) Exploitation competition, whereby $C$. fornicata and its basibiont compete for food resources. This trophic competition only operates when both species use the same food source. Since Crassostrea gigas seems to use different food sources than $C$. fornicata, as indicated by comparisons of $\delta^{13} \mathrm{C}$ and $\delta^{15} \mathrm{~N}$ values (Riera et al. 2002), this may explain the lack of evidence for competition in the experiment of Montaudouin et al. (1999). In contrast, for Mytilus edulis, competition with $C$. fornicata for food may occur, provided the food supply is limiting (Møhlenberg \& Riisgård 1978, Jørgensen et al. 1984, Lesser et al. 1992, Riera et al. 2002). Hence, for trophic competition to be lethal or 
to cause reduction in growth, it very much depends on locality and time, since the suspended food supply is variable. In conclusion, trophic exploitation competition between $C$. fornicata and its basibionts should be restricted to short periods and small-scale localities of food shortage. In contrast, interference competition by epizootic $C$. fornicata can be considered to occur on all basibionts that invest considerable energy in attachment, such as mussels and gastropods. Therefore, interference and not exploitation competition may be the major impact of epizootic C. fornicata on its basibionts on European coasts. However, to test the generality of this assumption, more C. fornicata-mollusc associations have to be investigated. This stresses the general need for a species-by-species approach under diverse environmental settings for assessing impacts of introduced species.

In the case of Mytilus edulis, the $30 \%$ mortality of overgrown mussels in the experiments indicate Crepidula fornicata to be a potentially important mortality factor for $M$. edulis in the field. Since $C$. fornicata mainly appears below the MLW, mussels in the subtidal should especially be affected. Observations in the field suggest that the dramatic effects proposed by these experimental results also occur at larger scales. Along the entire shore of the List tidal basin, mussel beds in the shallow subtidal were encountered with high $C$. fornicata abundance and almost no living mussels surviving. Since local abundance of $C$. fornicata in these areas can reach up to $2000 \mathrm{~m}^{-2}$, with virtually all mussels infested by $C$. fornicata, it seems likely that the limpet has caused die-offs of blue mussels, resulting in a displacement of a native filter-feeder by an introduced one. Since mussel-culture plots are also in the subtidal, $C$. fornicata has the potential to have strong economic effects when occurring in high densities. Today, superabundance of $C$. fornicata and hence the concomitant negative effects on mussels occur only locally where almost all mussels are infested by $C$. fornicata. Cold winters are supposed to have limited northern limpet populations so far (Thieltges et al. 2004). However, with a prognosed global warming resulting in milder winters (Beukema 1992, Meincke et al. 2003), a population increase of the species seems likely (Thieltges et al. 2004). The experimental results and local observations indicate that under such a scenario the slipper limpet has the potential to turn into a serious 'mussel pest', as already evidenced at a few localities.

Acknowledgements. I am grateful to C. Buschbaum, K. Reise, $M$. Strasser and 2 reviewers for their valuable comments on the manuscript and to N. Hernandez, I. Kruse, M. Landim, M. Pelzer, A. Rodriguez and N. Volkenborn for their help with setting up the field experiments. D. Poszig is thanked for everything else.

\section{LITERATURE CITED}

Ankel WE (1935) Die Pantoffelschnecke, ein Schädling der Auster. Nat Volk 65:173-176

Beukema JJ (1992) Expected changes in the Wadden Sea benthos in a warmer world: lessons from periods with mild winters. J Sea Res 30:73-79

Blanchard M (1997) Spread of the slipper limpet Crepidula fornicata (L. 1758) in Europe. Current state and consequences. Sci Mar 61:109-118

Branch GM (1984) Competition between marine organisms: ecological and evolutionary implications. Oceanogr Mar Biol Annu Rev 22:429-593

Buschbaum C, Reise K (1999) Effects of barnacle epibionts on the periwinkle Littorina littorea (L.). Helgol Mar Res 53:56-61

Buschbaum C, Saier B (2001) Growth of the mussel Mytilus edulis L. in the Wadden Sea affected by tidal emergence and barnacle epibionts. J Sea Res 45:27-36

Cohen AN, Carlton JT (1998) Accelerating invasion rate in a highly invaded estuary. Science 279:555-558

Day RW, Quinn GP (1989) Comparisons of treatments after an analysis of variance in ecology. Ecol Monogr 59:433-463

Dittmann S, Robles C (1991) Effect of algal epiphytes on the mussel Mytilus californianus. Ecology 72:286-296

Eno NC, Clark RA, Sanderson WG (1997) Non-native marine species in British waters: a review and directory. Joint Nature Conservation Committee, Peterborough

Gätje C, Reise K (1998) Ökosystem Wattenmeer, Austausch-, Transport- und Stoffumwandlungsprozessse. Springer, Berlin

Grosholz E (2002) Ecological and evolutionary consequences of coastal invasions. Trends Ecol Evol 17:22-27

Grosholz ED, Ruiz GM, Dean CA, Shirley KA, Maron JL, Connors PG (2000) The impacts of a nonindigenous marine predator in a California Bay. Ecology 81:1206-1224

Hayes KR, McEnnulty FR, Sliwa C (2002) Identifying potential marine pests - an inductive approach centre for research on introduced marine pests. Final Report for Environment Australia. National Priority Pests Project, Hobart

Jansson K (1994) Alien species in the marine environment: introductions to the Baltic Sea and the Swedish west coast. Report No. 4357, Swedish Environmental Protection Agency, Stockholm

Jørgensen CB, Kiørboe T, Møhlenberg F, Riisgård HU (1984) Ciliary and mucus-net filter feeding, with special reference to fluid mechanical characteristics. Mar Ecol Prog Ser 15:283-292

Kaufmann KW (1981) Fitting and using growth curves. Oecologia 49:293-299

Korringa P (1951) Crepidula fornicata as an oyster-pest. Rapp P-V Réun Cons Perm Int Explor Mer II 128:55-59

Lesser MP, Shumway SE, Cucci T, Smith J (1992) Impact of fouling organisms on mussel rope culture: interspecific competition for food among suspension-feeding invertebrates. J Exp Mar Biol Ecol 165:91-102

Lodge DM (1993) Biological invasions: lessons for ecology. Trends Ecol Evol 8:133-137

Lodge DM, Stein RA, Brown KM (1998) Predicting impact of freshwater exotic species on native biodiversity. Challenges in spatial scaling. Aust J Ecol 23:53-67

Meincke J, Quadfasel D, Berger WH, Brander K and 10 others (2003) Variability of the thermohaline circulation (THC). In: Wefer G, Lamy F, Mantoura F (eds) Marine science frontiers for Europe. Springer, Berlin, p 39-60

Møhlenberg F, Riisgård HU (1978) Efficiency of particle retention in 13 species of suspension feeding bivalves. Ophelia 17:239-246 
Montaudouin X de, Audemard C, Labourg PJ (1999) Does the slipper limpet (Crepidula fornicata, L.) impair oyster growth and zoobenthos biodiversity? A revisited hypothesis. J Exp Mar Biol Ecol 135:105-124

Nehls G (2000) Miesmuschelmonitoring im Nationalpark Schleswig-Holsteinisches Wattenmeer 1999. Landesamt für den Nationalpark Schleswig-Holsteinisches Wattenmeer, Tönning

Nehring S, Leuchs H (1999) Neozoa (Makrozoobenthos) an der deutschen Nordseeküste-eine Übersicht. Bundesanstalt für Gewässerkunde, Koblenz

Okamura B (1986) Group living and the effects of spatial position in aggregations of Mytilus edulis. Oecologia 69: 341-347

Olden JD, Poff NL, Douglas MR, Douglas ME, Fausch KD (2004) Ecological and evolutionary consequences of biotic homogenisation. Trends Ecol Evol 19:18-24

Orton JH (1927) Is the American slipper-limpet an oyster pest? Nautilus 40:102-103

Parker IM, Simberloff D, Lonsdale D, Goodel K and 7 others (1999) Impact. Towards a framework for understanding the ecological effects of invaders. Biol Invasions 1:3-19

Peterson CH (1983) Interactions between two infaunal bivalves, Chione undatella (Sowerby) and Protothaca staminea (Conrad), and two potential enemies, Crepidula onyx Sowerby and Cancer anthonyi (Rathbun). J Exp Mar Biol Ecol 68:145-158

Pimentel D (ed) (2002) Biological invasions-economic and

Editorial responsibility: Otto Kinne (Editor-in-Chief),

Oldendorf/Luhe, Germany environmental costs of alien plant, animal, and microbe species. CRC Press, Boca Raton, FL

Price HA (1983) Structure and formation of the byssus complex in Mytilus (Mollusca, Bivalvia). J Mollucan Stud 49: 9-17

Rice WR (1999) Analyzing tables of statistical tests. Evolution 43:223-225

Riera P, Stal LJ, Nieuwenhuize J (2002) $\delta^{13} \mathrm{C}$ versus $\delta^{15} \mathrm{~N}$ of cooccurring molluscs within a community dominated by Crassostrea gigas and Crepidula fornicata (Oosterschelde, The Netherlands). Mar Ecol Prog Ser 240:291-295

Ruiz GM, Fofonoff P, Hines AH, Grosholz ED (1999) Nonindigenous species as stressors in estuarine and marine communities: assessing invasion impacts and interactions. Limnol Oceanogr 44:950-972

Thieltges DW, Strasser M, Reise K (2003) The American slipper-limpet Crepidula fornicata (L.) in the Northern Wadden Sea 70 years after its introduction. Helgol Mar Res 57:27-33

Thieltges DW, Strasser M, Reise K (2004) Too cold to be happy-winter limits population increase of the introduced American slipper limpet Crepidula fornicata (L.) in northern Europe. J Exp Mar Biol Ecol 311:375-391

Werner B (1948) Die amerikanische Pantoffelschnecke Crepidula fornicata L. im nordfriesischen Wattenmeer. Zool Jahrb Abt Syst Ökol Geogr Tiere 77:449-488

Witman JD, Suchanek TH (1984) Mussels in flow: drag and dislodgement by epizoans. Mar Ecol Prog Ser 16:259-268

Submitted: March 8, 2004; Accepted: August 19, 2004

Proofs received from author(s): January 14, 2005 